Jurnal HELPER, Vol 36 No 2 (2019) 01 - 07

Bimbingan dan Konseling Universitas PGRI Adi Buana Surabaya

ISSN: 02162938

\title{
MENINGKATKAN EMPATI MELALUI PENDEKATAN KONSELING BEHAVIORAL TEKNIK KONTRAK PERILAKU PADA PESERTA DIDIK KELAS XI MIPA 5 SMA NEGERI 1 KALIANGET
}

\author{
Riyanti Utami \\ SMA Negeri 1 Kalianget \\ riyantiutami22@gmail.com
}

\author{
Akhmad Baihaqi \\ SMK Wali Songo 2 Gempol Pasuruan \\ mubah100@gmail.com
}

\begin{abstract}
Abstrak
Di zaman globalisasi ini atau biasa disebut dengan zaman modern menyebabkan semakin menipisnya empati pada diri tiap individu khususnya remaja. Semakin modern dunia semakin tinggi pula egoisme pada tiap remaja, sehingga kepedulian terhadap sesama sangat jarang dilakukan. Kenyataan yang ada saat ini kepedulian terhadap sesama manusia semakin menipis dan lebih disibukkan dengan kepedulian terhadap diri sendiri. Hal inilah yang menyebabkan timbulnya masalah sosial yang sering kita temui saat ini. Tujuan penelitian bimbingan konseling adalah untuk meningkatkan sikap empati menggunakan pendekatan behavioral teknik kontrak perilaku. Teknik analisa yang digunakan adalah teknik analisis kualitatif oleh Miles dan Huberman, yaitu teknik analisis interaktif. Hasil dari siklus I diperoleh skor empati 64 sedangkan siklus II diperoleh skor empati 80. Kemampuan empati perlu diasah setiap orang agar dirinya dapat menyesuaikan diri dengan lingkungan sekitarnya.

Kata Kunci: Empati, behavioral, kontrak perilaku.
\end{abstract}

\begin{abstract}
In this era of globalization or what is commonly referred to as modern times, it causes the depletion of empathy for each individual, especially adolescents. The more modern the world is, the higher the egoism of each teenager, so that caring for others is very rarely done. The fact that there is currently less concern for fellow human beings and is more preoccupied with caring for oneself. This is what causes the social problems that we often encounter today. The research objective of counseling guidance is to improve empathy using a behavioral approach to behavior contract techniques. The analysis technique used is qualitative analysis techniques by Miles and Huberman, namely interactive analysis techniques. The results of the first cycle obtained an empathy score of 64, while the second cycle obtained an empathy score of 80 . The ability of empathy needs to be honed by everyone so that they can adjust to their surroundings. Keywords: : Empathy, behavioral, behavioral contracts.
\end{abstract}


Jurnal HELPER, Vol 36 No 2 (2019) 01 - 07

Bimbingan dan Konseling Universitas PGRI Adi Buana Surabaya

ISSN: 02162938

\section{LATAR BELAKANG}

Kenyataan yang ada saat ini kepedulian terhadap sesama manusia semakin menipis dan lebih disibukkan dengan kepedulian terhadap diri sendiri.. Hal inilah yang menyebabkan timbulnya masalah sosial yang sering kita temui saat ini. Faktanya konflik pada remaja masih sering kita jumpai sekarang ini. Konflik-konflik tersebut yaitu masih banyaknya remaja yang berperilaku agresif, saling mencela ketika teman yang lain sedang mendapat masalah, diskriminasi sosial, tidak menghargai antar teman dan lain sebagainya. Hal ini menandakan bahwa sikap empati pada remaja sekarang ini masih minim bahkan belum terlihat.

Pada dasarnya empati adalah salah satu usaha seseorang untuk melakukan evaluasi diri sekaligus mengembangkan kontrol diri yang positif. Kemampuan melihat diri orang lain baik perasaan, pikiran maupun perilakunya merupakan bagian dari bagaimana orang itu akan merefleksikan keadaan tersebut dalam dirinya. Jika kita telah mempunyai kemampuan ini maka kita telah dapat mengembangkan kemampuan evaluasi diri yang baik dan akhirnya kita dapat melakukan kontrol diri yang baik artinya kita akan senantiasa berhati-hati dalam melakukan perbuatan atau memahami lingkungan sekitar kita.
Berdasarkan observasi yang telah dilakukan pada peserta didik di SMA Negeri 1 Kalianget terutama di kelas XI MIPA 5 terdapat peserta didik yang memperlihatkan sikap tidak empati, terlihat dari sikap yag ditampakkan oleh salah satu peserta didik yang tidak peduli dengan apa yang terjadi di sekitarnya, peserta didik tersebut lebih memilih acuh terhadap yang terjdi di sekitarnya, peserta didik tersebut kadang berkata kasar saat berbicara dan terlihat tingkat sikap pro-sosialnya rendah yang ditunjukkan dengan kurangnya untuk menolong, berempati, dan bekerja sama.

Guru BK menilai bahwa penelitian ini akan sangat penting karena kurangnya sikap empati pada peserta didik di SMA Negeri 1 Kalianget terutama di kelas XI MIPA 5 ini. Guru BK menilai bahwa sikap empati dapat dilatih dan akan sangat optimal bila dilakukan dengan pendekatan behavioral teknik kontrak perilaku terutama di lingkungan sekolah.

Berdasarkan uraian tersebut di atas penting sekali dilakukan penelitian mengenai "Upaya Meningkatkan Empati Dengan Pendekatan Behavioral Teknik Kontrak Perilaku Peserta Didik Kelas XI MIPA 5 SMA Negeri 1 Kalianget Tahun Pelajaran 2018/2019”.

Berdasarkan uraian latar belakang yang telah dikemukakan di atas, Secara khusus rumusan masalah tersebut dapat dijabarkan sebagai berikut "Apakah 
Jurnal HELPER, Vol 36 No 2 (2019) 01 - 07

Bimbingan dan Konseling Universitas PGRI Adi Buana Surabaya

ISSN: 02162938

pendekatan behavioral teknik kontrak perilaku dapat meningkatkan sikap empati peserta didik kelas XI MIPA 5 SMA Negeri 1 Kalianget Tahun Pelajaran 2018/2019?”

Berdasarkan rumusan masalah di atas maka tujuan dari pelaksanaan penelitian ini adalah sebagai berikut: Mendeskripsikan peningkatan aktivitas sikap empati menggunakan pendekatan behavioral teknik kontrak perilaku pada peserta didik kelas XI MIPA 5 SMA Negeri 1 Kalianget tahun pelajaran 2018/2019, Mendeskripsikan peningkatan hasil sikap empati menggunakan pendekatan behavioral teknik kontrak perilaku pada peserta didik Kelas XI MIPA 5 SMA Negeri 1 Kalianget tahun pelajaran 2018/2019.

\section{METODOLOGI PENELITIAN}

Pendekatan dalam penelitian tindakan bimbingan konseling ini adalah menggunakan pendekatan behavioral teknik kontrak perilaku yang dapat meningkatkan sikap empati peserta didik. Hal ini dikarenakan teknik pendekatan behavioral teknik kontrak perilaku diharapkan mampu menumbuhkan sikap peserta didik untuk menghargai dan berempati terhadap masalah yang dimiliki oleh orang lain.

Kegiatan penelitian tindakan kelas ini direncanakan 2 siklus. Penelitian ini diawali dengan kegiatan observasi sebagai penjajakan untuk memperoleh informasi tentang permasalahan yang sedang dihadapi, diteliti dan tindakan yang telah dilakukan oleh guru. Dan dilanjutkan dengan membahas hasil observasi serta merencanakan dan menetapkan tindakan.

Penelitian tindakan kelas ini dilakukan di SMA Negeri 1 Kalianget tahun pelajaran 2018/2019 dengan permasalahan "meningkatkan sikap empati pada peserta didik kelas XI MIPA 5 SMA Negeri 1 Kalianget tahun pelajaran 2018/2019”.

Subjek penelitian ini yaitu peserta didik kelas XI MIPA 5 SMA Negeri 1 Kalianget tahun pelajaran 2018/2019 dengan jumlah peserta didik sebanyak 30 siswa, lalu pemilihan subjek berdasarkan hasil need assessment, observasi dan wawancara, dan berdasarkan need assessment di peloleh 1 peserta didik yang memiliki skor empati rendah. Peserta didik yang mempunyai skor rendah tersebut di jadikan subjek penelitian.

Teknik dan instrumen pengumpulan data yaitu menggunakan skala sikap empati, observasi dan wawancara.

Teknik analisa yang digunakan adalah teknik analisis kualitatif oleh Miles dan Huberman, yaitu teknik analisis interaktif. Analisa interaktif terdiri atas tiga komponen, yaitu reduksi data, paparan data dan penarikan kesimpulan (Susilo, 2009:53). 
Jurnal HELPER, Vol 36 No 2 (2019) 01 - 07

Bimbingan dan Konseling Universitas PGRI Adi Buana Surabaya

ISSN: 02162938

\section{HASIL PENELITIAN}

Peneliti melancarkan need assessment di kelas XI MIPA 5 SMA Negeri 1 Kalianget tahun pelajaran 2018/2019. Peserta didik yang mengisi google form sebanyak 30 peserta didik . Data yang diperloleh ditemukan bahwa masih terdapat peserta didik di kelas XI MIPA 5 SMA Negeri 1 Kalianget tahun pelajaran 2018/2019 yang masih memiliki rasa empati yang rendah. Ada satu peserta didik yang skor empatinya rendah. Pengkategoriannya dapat dilihat dari tabel dibawah.

Tabel Pengkategorian Skala Empati

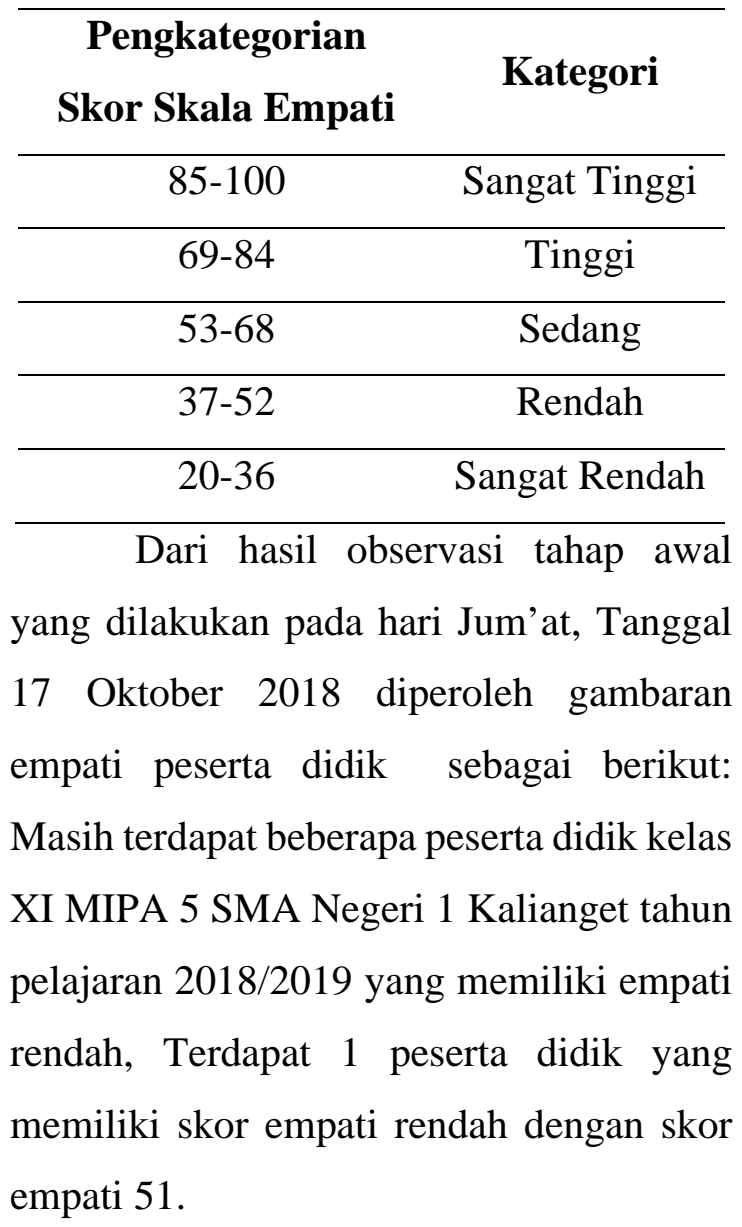

Skor empati peserta didik yang diperoleh dari observasi tahap awal terdapat pada tabel dibawah ini.

\begin{tabular}{cccc}
\hline No & Nama & $\begin{array}{c}\text { Hasil } \\
\text { Observasi Pra } \\
\text { Siklus }\end{array}$ & $\begin{array}{c}\text { Katagori } \\
\text { Empati }\end{array}$ \\
\hline 1 & AH & 74 & Tinggi \\
\hline 2 & BF & 80 & Tinggi \\
\hline 3 & FDS & 71 & Tinggi \\
\hline 4 & HH & 70 & Tinggi \\
\hline 5 & HR & 74 & Tinggi \\
\hline 6 & MDS & 75 & Tinggi \\
\hline 7 & LF & 80 & Tinggi \\
\hline 8 & NK & 74 & Tinggi \\
\hline 9 & WAA & 52 & Rendah \\
\hline 10 & P & 65 & Sedang \\
\hline 11 & MNIA & 66 & Sedang \\
\hline 12 & HL & 68 & Sedang \\
\hline 13 & NDP & 71 & Tinggi \\
\hline 14 & MRM & 57 & Sedang \\
\hline 15 & IB & 76 & Tinggi \\
\hline 16 & SW & 77 & Tinggi \\
\hline 17 & IBB & 76 & Tinggi \\
\hline 18 & FA & 70 & Tinggi \\
\hline 19 & ARP & 67 & Sedang \\
\hline 20 & AM & 52 & Rendah \\
\hline 21 & FSF & 83 & Tinggi \\
\hline 22 & SNQ & 65 & Sedang \\
\hline 23 & TM & 52 & Rendah \\
\hline 24 & ARP & 70 & Tinggi \\
\hline 25 & AF & 77 & Tinggi \\
\hline 26 & QS & 68 & Sedang \\
\hline 27 & RH & 62 & Sedang \\
\hline 28 & SR & 51 & Rendah \\
\hline 29 & FEA & 72 & Tinggi \\
\hline 30 & DAI & 70 & Tinggi \\
\hline & Dari & & diperol \\
\hline
\end{tabular}

Dari data tersebut, dapat diperoleh bahwa terdapat 18 orang peserta didik yang termasuk dalam kategori empati tinggi, 8 termasuk katagori sedang, dan 4 termasuk katagori rendah. Ada 4 peserta didik yang masuk dalam kategori rendah yaitu dengan 
Jurnal HELPER, Vol 36 No 2 (2019) 01 - 07

Bimbingan dan Konseling Universitas PGRI Adi Buana Surabaya

ISSN: 02162938

masing-masing mempunyai skor total 52 ada 3 anak dan mempunyai skor total 51 yaitu 1 anak, sehigga peneliti mengambil 1 anak tersebut yang mempunyai skor total terendah yaitu SR dengan skor 51 untuk di jadikan konseli dalam konseling individu.

Untuk mengatasi permasalahan peserta didik yang memiliki tingkat empati yang rendah tersebut, peneliti menerapkan pendekatan behavioral teknik kontrak perilaku. Pendekatan behavioral teknik kontrak perilaku ini dipilih karena dengan proses tersebut konseli yang mempunyai tingkat empati yang rendah tersebut akan berlatih menggunakan pendekatan behavioral teknik kontrak perilaku untuk memperbaiki tingkat empati yang rendah tersebut menjadi tinggi.

Dari hasil observasi siklus 1, pemberian tindakan konseling individu menggunakan pendekatan behavioral teknik kontrak perilaku yang semula mempunyai kategori empati rendah yaitu skor 51 naik menjadi kategori empati sedang yaitu dengan skor 64. Hasil pengisian angket skala empati tersebut diperoleh skor total konseli yaitu 64 dan termasuk dalam kategori sedang, menghasilkan data sebagai berikut:

\begin{tabular}{ccc}
\hline Nama & $\begin{array}{c}\text { Hasil } \\
\text { Observasi } \\
\text { Siklus 1 }\end{array}$ & $\begin{array}{c}\text { Katagori } \\
\text { Empati }\end{array}$ \\
\hline SR & 64 & Sedang \\
\hline
\end{tabular}

Data kategori empati konseli pada kategori sangat tinggi, tinggi, sedang dan rendah dapat dilihat melalui tabel berikut.

Tabel Pengkategorian Skala Empati

\begin{tabular}{cc}
\hline $\begin{array}{c}\text { Pengkategorian } \\
\text { Skor Skala Empati }\end{array}$ & Kategori \\
\hline $85-100$ & Sangat Tinggi \\
\hline $69-84$ & Tinggi \\
\hline $53-68$ & Sedang \\
\hline $37-52$ & Rendah \\
\hline $20-36$ & Sangat Rendah \\
\hline Dari hasil & observasi siklus 2,
\end{tabular}
pemberian tindakan konseling individu menggunakan pendekatan behavioral teknik kontrak perilaku yang semula mempunyai kategori empati sedang yaitu dengan skor 64 naik menjadi kategori empati tinggi yaitu dengan skor 80. Hasil pengisian angket skala empati tersebut diperoleh skor total konseli yaitu 80 dan termasuk dalam kategori tinggi, menghasilkan data sebagai berikut:

\begin{tabular}{ccc}
\hline Nama & $\begin{array}{c}\text { Hasil } \\
\text { Observasi } \\
\text { Siklus 1 }\end{array}$ & Katagori Empati \\
\hline SR & 80 & Tinggi \\
\hline \multicolumn{3}{c}{ Data kategori empati konseli pada }
\end{tabular}
kategori tinggi, rendah dan sedang, dapat dilihat melalui tabel berikut.

Tabel Pengkategorian Skala Empati

\begin{tabular}{cc}
\hline $\begin{array}{c}\text { Pengkategorian } \\
\text { Skor Skala Empati }\end{array}$ & Kategori \\
\hline $85-100$ & Sangat Tinggi \\
\hline $69-84$ & Tinggi \\
\hline $53-68$ & Sedang \\
\hline $37-52$ & Rendah \\
\hline $20-36$ & Sangat Rendah \\
\hline
\end{tabular}


Jurnal HELPER, Vol 36 No 2 (2019) 01 - 07

Bimbingan dan Konseling Universitas PGRI Adi Buana Surabaya

ISSN: 02162938

\section{PEMBAHASAN}

Penelitian tindakan bimbingan konseling ini dilakukan melalui dua siklus. Penelitian ini dilakukan untuk mengetahui peningkatan empati peserta didik melalui konseling individu dengan pendekatan behavioral teknik kontrak perilaku pada peserta didik kelas XI MIPA 5 SMA Negeri

1 Kalianget tahun pelajaran 2018/2019. Berdasarkan penelitian yang dilaksanakan, mulai dari observasi awal, siklus I dan siklus II diperoleh data sebagai berikut:

Tabel Rekapitulasi Data Skala Empati

\begin{tabular}{ccc}
\hline & $\begin{array}{c}\text { Skor Skala } \\
\text { Empati }\end{array}$ & $\begin{array}{c}\text { Kategori } \\
\text { Empati }\end{array}$ \\
\hline Pra & 51 & Rendah
\end{tabular}

Siklus

\begin{tabular}{lll}
\hline Siklus I & 64 & Sedang \\
\hline Siklus II & 80 & Tinggi \\
\hline
\end{tabular}

Untuk mengatasi permasalahan peserta didik yang memiliki tingkat empati yang rendah tersebut, peneliti melakukan konseling individu dengan menerapkan pendekatan behavioral teknik kontrak perilaku. Pendekatan behavioral teknik kontrak perilaku ini dipilih karena dengan proses tersebut konseli yang mempunyai tingkat empati yang rendah tersebut akan berlatih menggunakan pendekatan behavioral teknik kontrak perilaku untuk memperbaiki tingkat empati yang rendah tersebut menjadi tinggi

Berdasarkan hasil observasi dan panduan wawancara yang dilakukan dengan pendekatan behavioral teknik kontrak perilaku pada siklus I dan II terdapat peningkatan sikap empati berdasarkan aspek-aspeknya. Peserta didik terlihat antusias dan percaya diri dan juga terlihat dari tabel rekapitulasi data skala empati yang didapat peserta didik, yang mana pada prasiklus berada pada skala empati 51 yang termasuk kategori rendah, pada siklus 1 mengalami peningkatan pada skala empati yaitu 64 yang termasuk kategori sedang, dan pada siklus 2 mengalami peningkatan pada skala empati yaitu 80 yang termasuk kategori tinggi. Sehingga dapat disimpulkan dengan penggunaan Pendekatan behavioral teknik kontrak perilaku sangat efektif dalam mengubah sikap empati peserta didik.

\section{KESIMPULAN}

Empati adalah kemampuan seseorang dalam ikut merasakan atau menghayati perasaan dan pengalaman orang lain. seseorang tersebut tidak hanyut dalam suasana orang lain, tetapi memahami apa yang dirasakan orang lain itu. secara lebih luas empati diartikan sebagai ketrampilan sosial tidak sekedar ikut merasakan pengalaman orang lain, tetapi juga mampu melakukan respon kepedulian terhadap perasaan dan perilaku orang tersebut.

\section{SARAN}


Jurnal HELPER, Vol 36 No 2 (2019) 01 - 07

Bimbingan dan Konseling Universitas PGRI Adi Buana Surabaya

ISSN: 02162938

Penulis mencoba akan memberikan sedikit saran yang mudah-mudahan bisa bersifat membangun yang di dasarkan pada hasil dari penelitian ini yakni: Hendaknya guru tidak hanya menekankan aspek kognitifnya saja akan tetapi lebih menekankan juga aspek psikomotorik dan aspek afektif, Hendaknya bagi seorang guru haruslah dapat menjadi suri tauladan yang baik bagi para siswanya. Sebab sikap dan tingkah laku guru menjadi perhatian khusus bagi para siswanya di sekolah.

\section{DAFTAR PUSTAKA}

Alberto, P.A. \& Troutman, A.C. Aplikasi Analisis Behavioral Untuk Guru. (Columbus, OH: 2009)

Arikunto, Suharsimi. (2006). Prosedur Penelitian Suatu Pendekatan. Jakarta: Rineka Cipta.

Asri Budiningsih. 2004. Pembelajaran Moral. Jakarta: Rineka Cipta.

Fauzan, lutfi. 2009. Kontrak Perilaku. Dalam http://lutfifauzan. wordpress.com/2009/08/09/kontrak -perilaku

Goleman, Daniel. (2007). Kecerdasan Emosinal: Mengapa EI Lebih
Penting daripada IQ. (alih bahasa: T. Hermaya). Jakarta: PT Gramedia Pustaka Utama.

Hidayah, N. 1998. Pemahaman Individu: Teknik Non Tes. Malang: Fakultas Pertanian Universitas Brawijaya.

Komalasari, G. Dkk (2011). Teori Dan Teknik Konseling. Jakarta: PT. Indeks

Latipun, (2008). Psikologi Konseling. Malang: UMM Press.

Mujursejathi. 2011. Teknik-teknik Behavior Konseling.

Online http://id.shvoong.com/socialscience s/education/2173602-teknik-teknikbehaviour-

konseling/\#ixzz1dq59YamI.

Robert A. Baron dan Donn Byrne. 2005. Psikologi Sosial. (alih bahasa: Ratna Djuwita). Jakarta: Erlangga.

Suharsimi Arikunto. (2012). Prosedur Penelitian: Suatu Pendekatan Praktik. Jakarta: Rineka Cipta.

Susilo, H., dkk. 2009. Penelitian Tindakan Kelas. Malang: Bayumedia.

Suwarsih Madya. (2007). Teori dan Praktek Penelitian Tindakan. Bandung: Alpabeta.

Taufik. (2012). Empati Pendekatan Psikologi Sosial. Jakarta: Raja Grafindo Persada. 